\title{
RADIOPROTECTIVE PROPERTIES OF SODIUM HUMATE IN RADIATION-INDUCED MUTAGENESIS IN CULTURED LYMPHOCYTES OF THYROID CANCER PATIENTS
}

\author{
V.M. Shkarupa*, S.V. Klymenko \\ State Institution "National Research Centre for Radiation Medicine of National Academy of Medical \\ Sciences of Ukraine”, Kyiv 04050, Ukraine
}

\begin{abstract}
Aim: To investigate the effect of sodium humate on the level of cytogenetic damage in culture of lymphocytes of patients with thyroid cancer after $\gamma$-irradiation. Materials and Methods: Metaphase analysis of chromosome aberrations in cultured peripheral blood lymphocytes of 10 individuals with thyroid cancer was performed after irradiation of lymphocytes in vitro at a dose of $1 \mathrm{~Gy}$ from ${ }^{137} \mathrm{Cs}$ source at the early $G_{0}$ phase of cell cycle. Sodium humate was added to cell culture for $30 \pm 15$ min after phytohemagglutinin stimulation at concentrations of 10 and $100 \mu \mathrm{g} / \mathrm{ml}$. Results: Sodium humate exhibited antimutagenic properties. The preparation at a concentration of $10 \mu \mathrm{g} / \mathrm{ml}$ was more effective than at a concentration of $100 \mu \mathrm{g} / \mathrm{ml}$, reducing the average incidence of radiation-induced chromosome aberrations by $\mathbf{5 1 . 8 8}$ and $\mathbf{3 8 . 7 7 \%}$, respectively. The most pronounced antimutagenic effect of sodium humate was the reduction of the frequency of chromosomal type aberrations, however, such efficiency varied between individual patients with thyroid cancer. Conclusions: Sodium humate could be considered as a potential therapeutic modifier of radiation damage.
\end{abstract}

Key Words: thyroid cancer, $\gamma$-irradiation, chromosome aberrations, sodium humate.

Currently, the scientific literature presents numerous data on biological activity of humic substances. Their preparations are being used both in medicine and agriculture [1-4]. Humic substances are a complex of natural polymer compounds, products of humification, which are present in the soil, peat, brown coal, sapropel, etc. The main component of the humic substances is humic acid, which physiologically active form is salts (humates). The feature of humic substances is the saturation of their molecules by most diverse functional groups, namely carboxyl, phenolic and alcoholic hydroxyls, quinoid groups, methoxy, amino and amido groups [1] that ultimately provides the widest range of their biological activity [2-4]. Particular attention is drawn to antitumor properties of humic substances. Their antiangiogenic and proapoptotic properties are found as well [5-7]. Antitumor activity of humic substances was showed in various models of transplantable tumors, spontaneous and induced tumors, in human tumor cell lines [8]. Moreover, humic substances are characterized as non-toxic [4]. Noteworthy that preparations of humic substances with antitumor activity do not have long-term adverse effects [9].

In the last decade intense studies of humic substances have shown the potential of a significant extending of their pharmacological application. The scientific literature describes their antioxidant, immunostimulatory, anti-inflammatory and antiviral effects [1-4, 10-12]. It was shown that humic substances may change the expression profile of more than 30 genes, and affect DNA methylation [13, 14]. Considering adaptogenic and immune-stimulating properties of humic substances, their ability to increase non-specific resistance of a human body could

Submitted: April 12, 2016.

*Correspondence: E-mail: Shkarupa_vlad@bigmir.net be assumed [1-4, 10-12]. There is an increasing interest in the study of their use in cancer radiotherapy to protect normal tissues, to improve the tolerability of the treatment, and to reduce the risk of early and late side effects. One of these effects of radiotherapy is its significant mutagenic effect on non-transformed cells, in particular of hematopoietic system, which increases the risk of secondary cancer. It should be noted, that most of studies testing this hypothesis were performed in culture of lymphocytes of healthy individuals. There are few publications describing studies of spontaneous and induced mutagenesis in diseased persons, especially in cancer patients $[15,16]$.

Thyroid cancer is one of the most severe consequences of the Chornobyl accident. Increased quantity of TCR-mutant cells in patients with thyroid cancer was revealed that may be due to genotoxic effects, increased by genetic instability (especially radiation-induced) [17]. In patients with thyroid cancer living in areas contaminated with radionuclides, there was found an increased level of cytogenetic damage in cultured peripheral blood lymphocytes [15]. This makes reasonable the attempts to modify radiationinduced mutagenesis in somatic cells of patients with thyroid cancer.

The aim of this work was to investigate the effect of sodium humate on the level of cytogenetic damage in cultured lymphocytes of patients with thyroid cancer after $\gamma$-irradiation.

\section{MATERIALS AND METHODS}

Metaphase analysis of chromosomal aberrations in peripheral blood lymphocyte cultures was carried out in 10 thyroid cancer patients. The patients were treated in National Research Center for Radiation Medicine of National Academy of Medical Sciences of Ukraine. The study has been performed in accordance with ethics rules for biomedical research. All 
patients gave an informed consent for the participation in the study.

Irradiation of lymphocytes was held in vitro at a dose of $1 \mathrm{~Gy}$ from ${ }^{137} \mathrm{Cs}$ source (IBL $437 \mathrm{C}$, France, dose rate $-2.46 \mathrm{~Gy} / \mathrm{min}$ ) in the early $\mathrm{G}_{0}$ phase of the cell cycle. After phytohemagglutinin stimulation, during $30 \pm 15$ min after radiation exposure, sodium humate (Agrohimpak, Ukraine) was added to the culture of lymphocytes at concentrations of 10 or $100 \mu \mathrm{g} / \mathrm{ml}$. In each case, at least 100 metaphases were examined for numerical as well as structural aberrations. The average group indexes were calculated as the ratio of the total number of chromosomal aberrations to the total number of analyzed cells. Antimutagenic activity was determined by a reduction in the frequency of chromosome aberrations that was calculated as a percentage. Probability of differences was assessed by the criterion of Fisher.

\section{RESULTS AND DISCUSSION}

Table 1 shows the results of analysis of the sodium humate impact on the frequency of spontaneous and radiation-induced chromosome aberrations in lymphocyte cultures of thyroid cancer patients.

Table 1. Antimutagenic effect of sodium humate in the culture of peripheral blood lymphocytes of patients with thyroid cancer after irradiation in vitro at a dose of $1 \mathrm{~Gy}$ from ${ }^{137} \mathrm{Cs}$

\begin{tabular}{lcc}
\hline \multicolumn{1}{c}{ Treatment } & $\begin{array}{c}\text { Frequency } \\
\text { of chromosome } \\
\text { aberrations per } \\
100 \text { cells }\end{array}$ & $\begin{array}{c}\text { Anti- } \\
\text { muta- }\end{array}$ \\
$\begin{array}{lcc}\text { genic ef- } \\
\text { fect, } \%\end{array}$ \\
\hline Control & $3.75 \pm 0.51$ & - \\
Sodium humate, $10 \mu \mathrm{g} / \mathrm{ml}$ & $2.61 \pm 0.46^{*}$ & - \\
Sodium humate, $100 \mu \mathrm{g} / \mathrm{ml}$ & $3.65 \pm 0.52$ & - \\
Irradiation, $1 \mathrm{~Gy}$ & $21.51 \pm 0.95$ & - \\
Irradiation, $1 \mathrm{~Gy}+$ sodium humate, $10 \mu \mathrm{g} / \mathrm{ml}$ & $10.35 \pm 0.66^{\star *}$ & $51.88^{\star * *}$ \\
Irradiation, $1 \mathrm{~Gy}+$ sodium humate, $100 \mu \mathrm{g} / \mathrm{ml}$ & $13.17 \pm 0.69^{\star *}$ & 38.77 \\
\hline Note: ${ }^{*} p=0.08 \mathrm{compared}$ to untreated control; ${ }^{* *} p<0.05$ compared to the \\
effect of irradiation; ${ }^{* * *} p<0.05$ compared to irradiation, 1 Gy with addition \\
of sodium humate, $100 \mu \mathrm{g} / \mathrm{ml}$.
\end{tabular}

The average spontaneous frequency of chromosome aberrations was $3.75 \pm 0.51$ aberrations per 100 cells. However, a range of minimal and maximal individual values of this index varied from 0.00 to $8.15 \pm 2.36$ aberrations per 100 cells. Sodium humate at a concentration of $100 \mu \mathrm{g} / \mathrm{ml}$ did not reduce the mean values of spontaneous mutagenesis. The tendency to reduce the average frequency of spontaneous aberrations in cultured lymphocytes of thyroid cancer patients $(2.61 \pm 0.46$ aberrations/100 cells) modified by humic preparation at a concentration of $10 \mu \mathrm{g} / \mathrm{ml}$ had insufficient level of statistical significance $(p=0.08)$. The average frequency of chromosome aberrations in cultured lymphocytes of patients with thyroid cancer after irradiation in vitro was $21.51 \pm$ 0.95 aberrations $/ 100$ cells. The range of minimal and maximal individual values of this index varied from $13.16 \pm 2.49$ to $27.50 \pm 4.08$ aberrations per 100 cells. Addition of sodium humate after exposure has shown an expressed antimutagenic effect. Antimutagenic efficiency of sodium humate at a concentration of $10 \mu \mathrm{g} / \mathrm{ml}$ (antimutagenic effect $-51.88 \%$ ) was significantly higher $(p<0.05)$ than by the impact of the preparation at a concentration of $100 \mu \mathrm{g} / \mathrm{ml}$ (antimutagenic effect $-38.77 \%$ ).

Reduction of the radiation-induced chromosome aberrations frequency as a result of the sodium humate action was mainly due to the decrease of aberrations of chromosomal type (Table 2). Reduction of the average frequency of aberrations of chromatide type to $26.44 \%$ by addition of the preparation at a concentration of $10 \mu \mathrm{g} / \mathrm{ml}$, and to $24.92 \%$ by addition of the preparation at a concentration of $100 \mu \mathrm{g} / \mathrm{ml}$ had not reached statistical significance.

Table 2. Effect of sodium humate on the frequency of radiation-induced chromosomal and chromatide type aberrations (average value)

\begin{tabular}{|c|c|c|c|c|}
\hline Treatment & $\begin{array}{c}\text { Frequen- } \\
\text { cy of chroma- } \\
\text { tide type aber- } \\
\text { rations per } \\
100 \text { cells }\end{array}$ & $\begin{array}{c}\text { Anti- } \\
\text { muta- } \\
\text { genic } \\
\text { effect, } \\
\% \\
\end{array}$ & $\begin{array}{c}\text { Frequen- } \\
\text { cy of chromo- } \\
\text { somal type } \\
\text { aberrations } \\
\text { per } 100 \text { cells }\end{array}$ & $\begin{array}{c}\text { Anti- } \\
\text { muta- } \\
\text { genic } \\
\text { effect, } \\
\% \\
\end{array}$ \\
\hline Irra & 3.29 & & 0.90 & \\
\hline $\begin{array}{l}\text { Irradiation, } 1 \mathrm{G} \\
\text { um humate, } 10\end{array}$ & 2.42 & 26.44 & $.58^{\star}$ & $56.53^{\star}$ \\
\hline $\begin{array}{l}\text { Irradiation, } 1 \mathrm{~Gy}+\text { sodi- } \\
\text { um humate, } 100 \mu \mathrm{g} / \mathrm{ml}\end{array}$ & $2.47 \pm 0.32$ & 24.92 & $10.70 \pm 0.63^{\star}$ & $41.27^{\star}$ \\
\hline
\end{tabular}

Note: ${ }^{*} p<0.05$ as compared to the effect of irradiation.

Analysis of cytogenetic indexes at the individual level (Table 3 and 4 ) found significant differences in the response on radiation exposure and antimutagenic effect of sodium humate.

Table 3. Individual indexes of antimutagenic effect of sodium humate $(10 \mu \mathrm{g} / \mathrm{ml})$ in the culture of peripheral blood lymphocytes of patients with thyroid cancer after irradiation in vitro at a dose of $1 \mathrm{~Gy}$ from ${ }^{137} \mathrm{Cs}$

\begin{tabular}{|c|c|c|c|c|c|}
\hline \multirow{2}{*}{$\begin{array}{c}\text { Culture } \\
\text { of lym- } \\
\text { phocytes, } \\
\text { pa- } \\
\text { tient's ID }\end{array}$} & \multicolumn{4}{|c|}{ Frequency of chromosome aberrations per 100 cells } & \multirow[b]{2}{*}{$\begin{array}{c}\text { Anti- } \\
\text { muta- } \\
\text { genic } \\
\text { effect, } \\
\% \\
\end{array}$} \\
\hline & & $\begin{array}{l}\text { Sodium hu- } \\
\text { mate } \\
(10 \mu \mathrm{g} / \mathrm{ml})\end{array}$ & $\begin{array}{c}\text { Irradiation, } \\
1 \mathrm{~Gy}\end{array}$ & $\begin{array}{c}\text { Irradiation, } \\
1 \text { Gy + sodium } \\
\text { humate } \\
(10 \mu \mathrm{g} / \mathrm{ml})\end{array}$ & \\
\hline $\mathrm{T}_{1}$ & & & & $9.55 \pm 1.98^{\star \star}$ & 46.94 \\
\hline$T$ & & & & & \\
\hline & & & & & \\
\hline$\tau$ & & & & & \\
\hline & & & & & \\
\hline & & & & & \\
\hline & & & & & \\
\hline & & & & & \\
\hline & & & & ** & 63.3 \\
\hline & & & \pm & $18.50 \pm 2.75^{\star \star}$ & \\
\hline
\end{tabular}
Note: ${ }^{*} p<0.05$ compared to untreated control; ${ }^{* *} p<0.05$ compared to the effect of irradiation; ${ }^{* * \star} p>0.05$ compared to the effect of irradiation.

Table 4. Individual indexes of antimutagenic effects of sodium humate $(100 \mu \mathrm{g} / \mathrm{ml})$ in the culture of peripheral blood lymphocytes of patients with thyroid cancer after irradiation in vitro at a dose of $1 \mathrm{~Gy}{ }^{137} \mathrm{Cs}$

\begin{tabular}{|c|c|c|c|c|c|}
\hline \multirow[b]{2}{*}{$\begin{array}{c}\text { Culture } \\
\text { of lym- } \\
\text { phocytes, } \\
\text { pati- } \\
\text { ent's ID }\end{array}$} & \multicolumn{4}{|c|}{ Frequency of chromosome aberrations per 100 cells } & \multirow[b]{2}{*}{$\begin{array}{l}\text { Anti- } \\
\text { muta- } \\
\text { genic } \\
\text { effect, } \\
\% \\
\end{array}$} \\
\hline & Control & $\begin{array}{c}\text { Sodium } \\
\text { humate } \\
(100 \mu \mathrm{g} / \mathrm{ml})\end{array}$ & $\begin{array}{l}\text { Irradiation, } \\
1 \text { Gy }\end{array}$ & $\begin{array}{l}\text { Irradiation, } \\
1 \text { Gy + sodi- } \\
\text { um humate } \\
(100 \mu \mathrm{g} / \mathrm{ml})\end{array}$ & \\
\hline $\mathrm{T}_{1}$ & & & & $02^{\star \star}$ & 44.44 \\
\hline & & & & & \\
\hline$\tau$ & & & & & \\
\hline & & & & & \\
\hline & & & & & \\
\hline & & & & & \\
\hline & & & & & \\
\hline & & & & & -17 \\
\hline & & & & & \\
\hline & & & & & \\
\hline
\end{tabular}

Note: ${ }^{*} p<0.05$ compared to untreated control; ${ }^{\star \star} p<0.05$ compared to the effect of irradiation; ${ }^{* \star} p>0.05$ compared to the effect of irradiation.

Most researchers believe that if the preparation reduces the induced damage by less than $10 \%$, 
it could not be considered antimutagenic. Substances that reduce the frequency of aberrations at the range of $10.1-20.0 \%$ usually are being called "very weak", and at in the range of $20.1-40.0 \%$ - "weak" antimutagens. Reducing the frequency of aberrations by $40.1-80.0 \%$ is typical for the majority of antimutagens of "average" performance. Substances, that can reduce the level of induced damage by more than $80 \%$, are related to the group of "strong" antimutagens [18]. In cultures of lymphocytes of patients $\mathrm{T}_{7}$ and $\mathrm{T}_{8}$ sodium humate did not show antimutagenic properties. In a lymphocyte culture of patient $\mathrm{T}_{4}$ weak antimutagenic activity of humic preparation (25.91\% at a concentration of $10 \mu \mathrm{g} / \mathrm{ml}$ and $29.64 \%$ at a concentration of $100 \mu \mathrm{g} / \mathrm{ml}$ ) had insufficient statistical significance. In other cases, sodium humate has showed the properties of antimutagen of "average efficiency". Antimutagenic effect of sodium humate did not depend on the level of spontaneous or initial radiation-induced mutagenesis.

In the context of possible modifying of the spontaneous and induced mutagenesis in the culture of human lymphocytes the study on radioprotective properties of timalin should be mentioned $[15,16]$. In the culture of lymphocytes of thyroid cancer patients, who reside in the territories of Ukraine with increased density of radioactive contamination from the Chornobyl accident, timalin reduced the average level of spontaneous chromosome aberrations from $6.0 \pm 0.7$ to $2.0 \pm 0.5 \%$ [15]. In our study, the average frequency of chromosome aberrations induced by sodium humate at a concentration of $10 \mu \mathrm{g} / \mathrm{ml}$ was similar and amounted to $2.61 \pm 0.46$ aberrations per 100 cells, although the spontaneous frequency was lower and amounted to $3.75 \pm 0.51$ aberrations per 100 cells. It is possible that studied substances can reduce the frequency of spontaneous chromosome aberrations only to a certain level, or under particular circumstances of increased spontaneous mutagenesis.

In a situation, where the individual frequency of spontaneous chromosome aberrations in the cultured lymphocytes of thyroid cancer patients was within the average population values (0-3 aberrations per 100 cells), it showed no reduction of spontaneous level by addition of sodium humate. Among those with high levels of spontaneous mutagenesis, antimutagenic effect of sodium humate manifested in lymphocyte cultures of two patients $\left(T_{9}\right.$ and $\left.T_{10}\right)$, in one of which $\left(T_{9}\right)$ preparation in both studied concentrations leads to the significant reduction of spontaneous frequency of chromosome aberrations.

Dyomina [15] have shown that the timalin added to cultured lymphocytes of thyroid cancer patients irradiated at a dose of $0.3 \mathrm{~Gy}$, reduced the percentage of aberrant cells from $9.0 \pm 1.7$ to $2.1 \pm 1.0 \%$, compared to irradiated control. So, timalin could be effective if added before irradiation [19]. During timalin action on lymphocytes at $G_{1}$ phase of cell cycle subsequently exposed to a high dose irradiation
(2 Gy), the author observed an opposite cytogenetic effect, an increased frequency of radiation-induced aberrations from $18.0 \pm 1.9$ to $26.0 \pm 2.5 \%$, which was explained by timalin influence on radiation-induced mitotic delay [16]. The essential difference between these data and our study was that sodium humate showed antimutagenic effectiveness by its action after irradiation exposure. This allows considering it as a potential therapeutic modifier of radiation damage [19].

It is believed that effectiveness of radioprotective substances after cell irradiation could be caused by activation of DNA repair or other irradiation recovery processes, in particular stimulation of repopulation [19]. Repopulation as a reaction of organisms to irradiation exposure was studied in detail in many model systems, including its stimulation by antimutagens [19-21]. Well-known adaptogenic properties of humates suppose their impact also on other processes of post-radiation recovery [1-4]. The view on mechanisms of radioprotective action of sodium humate in the culture of human lymphocytes is supported by the results of our previous studies done in plant test-system. In particular, the multiplicity of genoprotective mechanisms of humic substances, including the activating reparation processes and stimulation of repopulation has been shown [22].

In conclusion, antimutagenic effect of sodium humate was revealed, what allows to consider it as potential therapeutic modifier of radiation damage. The preparation at a concentration of $10 \mu \mathrm{g} / \mathrm{ml}$ was more effective than at a concentration of $100 \mu \mathrm{g} / \mathrm{ml}$, reducing the average incidence of radiation-induced chromosome aberrations by 51.88 and $38.77 \%$, respectively. Antimutagenic effect was manifested mainly by reduction of the frequency of chromosome type aberrations. There were individual differences in antimutagenic efficacy of sodium humate in cultured lymphocytes of thyroid cancer patients.

\section{REFERENCES}

1. Pena-Mendez EM, Havel J, Patocka J. Humic substances - compounds of still unknown structure: applications in agriculture, industry, environment, and biomedicine. J Appl Biomed 2005; 3: 13-24.

2. Klöcking R, Helbig B. Medical aspects and applications of humic substances. In: Biopolymers for Medical and Pharmaceutical Applications. Steinbüchel A, Marchessault RH, Eds. Weinheim: Wiley-VCH Verlag GmbH \& Co, 2005: 3-15.

3. Zhou XP, Zhang YC, Zhang SW, et al. New progress in medical research of bio-humic acid. Appl Mech Mater 2012; 138-139: 1228-33.

4. Buzlama AV. Experimental study of pharmacological properties of humic acid salts [dissertation]. Voronezh: Voronezh State Medical University named after N.N. Burdenko, 2014. 410 p. (in Russian).

5. Pant K, Singh B, Thakur N. Shilajit: a humic matter panacea for cancer. Int J Toxicol Pharmacol Res 2012; 2: $17-25$.

6. Rayhlin NT, Blanko FF, Stepanova EV, et al. Study of anti-angiogenic properties of new drug butafol. Russ J Bioter 2007; 6: 49 (in Russian). 
7. Yang HL, Hseu YC, Hseu YT, et al. Humic acid induces apoptosis in human premyelocytic leukemia HL-60 cells. Life Sci 2004; 75: 1817-31.

8. Filov VA, Reztsova VV, Kil'maeva NE, et al. Experimental study of antitumor properties of olypiphate. Vopr Oncologii 2000; 46: 332-6 (in Russian).

9. Revasova YuA, Gus'kova TA, Khudoley VV, Filov VA. The study of remote effects of olypiphate. Exp Oncol 2003; 25: 256-9.

10. Inglot AD, Zielińska-Jenczylik J, Piasecki E. Tołpa Torf Preparation (TTP) induces interferon and tumor necrosis factor production in human peripheral blood leukocytes. Arch Immunol Ther Exp (Warsz) 1993; 41: 73-80.

11. van Rensburg CE, Dekker J, Weis $R$, et al. Investigation of the anti-HIV properties of oxihumate. Chemotherapy 2002; 48: 138-43.

12. van Rensburg CE. The antiinflammatory properties of humic substances: a mini review. Phytother Res 2015; 29: $791-5$.

13. Trevisan $S$, Botton $A$, Vaccaro $S$, et al. Humic substances affect Arabidopsis physiology by altering the expression of genes involved in primary metabolism, growth and development. Environ Exp Bot 2011; 74: 45-55.

14. Yildirim N, Agar G, Taspinar MS, et al. Protective role of humic acids against dicamba-induced genotoxicity and DNA methylation in Phaseolus vulgaris L. Acta Agric Scand B Soil Plant Sci 2014; 64: 141-8.
15. Dyomina EA. Cytogenetic effects in somatic cells of patients with thyroid gland cancer. Visn Ukr Tov Genet Sel 2008; 6: 52-9 (in Ukrainian).

16. Grinevich YuA, Demina EA. Immune and cytogenetic effects of dense and rare ionizing radiation. Kyiv: Zdorov'ya, 2006. 200 p. (in Russian).

17. Vereshchagina AO, Zamulaeva IA, Orlova NV. Frequency of mutant lymphocites in T-cell reseptor locus as a possible predictor of thyroid cancer development in irradiated and unirradiated persons. Radiats Biol Radioecol 2005; 45: 653-6 (in Russian).

18. Semenov VV, Studentsova IA. Quantitative and qualitative criteria for evaluating the effectiveness of the experiment in antimutagens. Vestn Ross Akad Med Nauk 1993; (3): 16-20 (in Russian).

19. Grodzinsky DM. Radiobiology. Kyiv: Lybid, 2000. 448 p. (in Ukrainian).

20. Serebrianyi AM, Zoz NN, Morozova IS. On antimutagenesis mechanism in plants. Genetika 2005; 41: 676-9 (in Russian).

21. Serebrianyi AM, Aleshchenko AV, Gotlib VYa, et al. On the new mechanism of adaptive response. Radiats Biol Radioecol 2004; 44: 653-6 (in Russian).

22. Shkarupa VM, Klymenko SV, Talko VV. Cytogenetic analysis of radioprotective properties of sodium lignogumate after $\gamma$-exposure in Allium-test. Probl Radiat Med Radiobiol 2014; 19: 490-508. 